\title{
Duodenal intramural hematoma due to early postoperative anticoagulant treatment after a renal transplant: A case report
}

\author{
Adem Bayraktar, M.D., (1) Leman Damla Ercan, M.D., () Hüseyin Bakkaloğlu, M.D., \\ 다 Ali Fuat Kaan Gök, M.D., 다 Mehmet İlhan, M.D., 도 Ali Emin Aydın, M.D.
}

Department of General Surgery, İstanbul University İstanbul Faculty of Medicine, İstanbul-Turkey

\begin{abstract}
A spontaneous intramural duodenal hematoma is a rare complication in patients receiving anticoagulation therapy. Presently described is a case of intramural duodenal hematoma in a patient with a cadaveric renal transplant who was under oral anticoagulant treatment due to paroxysmal atrial fibrillation. The patient was admitted with intense abdominal pain, nausea, vomiting, and a total obstruction of duodenum. After a diagnosis of intramural hematoma, a good prognosis was achieved with conservative care.
\end{abstract}

Keywords: Anticoagulant; intramural duodenal hematoma, renal transplantation.

\section{INTRODUCTION}

The intramural duodenal hematoma was first reported as " $a$ false aneurysm" of the intestinal wall by McLauchlan during an autopsy in 1838. ${ }^{[1]}$ An intramural duodenal hematoma usually occurs secondary to blunt abdominal trauma. ${ }^{[2,3]}$ There are cases in the literature where an intramural duodenal hematoma occurs spontaneously and consequently the patient presents with abdominal pain due to partial gut obstruction. Spontaneous intramural duodenal hematomas are commonly associated with coagulopathy, anticoagulating drugs or sometimes with endoscopic procedures. ${ }^{[4-7]}$ Warfarin is one of the usual suspects in these cases with a frequency of one case per 2500 anticoaugulated patients annually. ${ }^{[8]}$

\section{CASE REPORT}

Fourty eight years old female patient had a cadaveric renal transplantation for end-stage renal disease secondary to hypertension and vesicoureteral reflux. She suffered early post-operative tachycardia diagnosed as paroxysmal atrial fibrillation which was managed with warfarin therapy. At the time of her discharge renal functions were normal and the
International Normalised Ratio (INR) level was 2.I. Approximately 45 days after the transplant she was admitted to the emergency department with a two days history of epigastric pain, nausea and recurrent vomiting with no prior history of trauma. Abdominal examination was non-specific except for a relatively mild epigastric tenderness. Laboratory workup showed an increase in white cell count (14000 cells $\left./ \mathrm{mm}^{3}\right)$, but both liver and kidney functions were normal (creatine: $0.7 \mathrm{mg} / \mathrm{dL}$ ). INR was 6.2 at the time and she was given fresh frozen plasma (FFP)/vitamin $\mathrm{K}$ combination to reduce INR levels. Plain graphies of the abdomen suggested intestinal obstruction. A nasogastric (NG) tube was inserted and I500 cc bile colored intestinal fluid aspirated.

Upper gastrointestinal (UGI) water soluble contrast series showed minimal contrast passage to distal part and a collection of the barium in the $3^{\text {rd }}$ portion of the duodenum (Fig. la, b). A subsequent UGI endoscopy confirmed dilatation of the $3^{\text {rd }}$ portion of the duodenum and a total obstruction with an accumulation of drug tablets proximal to this level (Fig. Ic, d). CT scan of the abdomen/pelvis region with oral contrast demonstrated a non-enhanced, mildly hyperdense duo-

Cite this article as: Bayraktar A, Ercan LD, Bakkaloğlu H, Gök AFK, İlhan M, Aydın AE. Duodenal intramural hematoma due to early postoperative anticoagulant treatment after a renal transplant: A case report. Ulus Travma Acil Cerrahi Derg 2018;24:594-596.

Address for correspondence: Adem Bayraktar, M.D.

İstanbul Üniversitesi İstanbul Tıp Fakültesi, Genel Cerrahi Anabilim Dalı, İstanbul, Turkey

Tel: +90 212 - 4142000 E-mail: dradem6I@gmail.com

Ulus Travma Acil Cerrahi Derg 2018;24(6):594-596 DOI: 10.5505/tjtes.2018.43637 Submitted: 13.09.2018 Accepted: 24.11 .2018 Online: 29.1I.2018

Copyright 2018 Turkish Association of Trauma and Emergency Surgery 

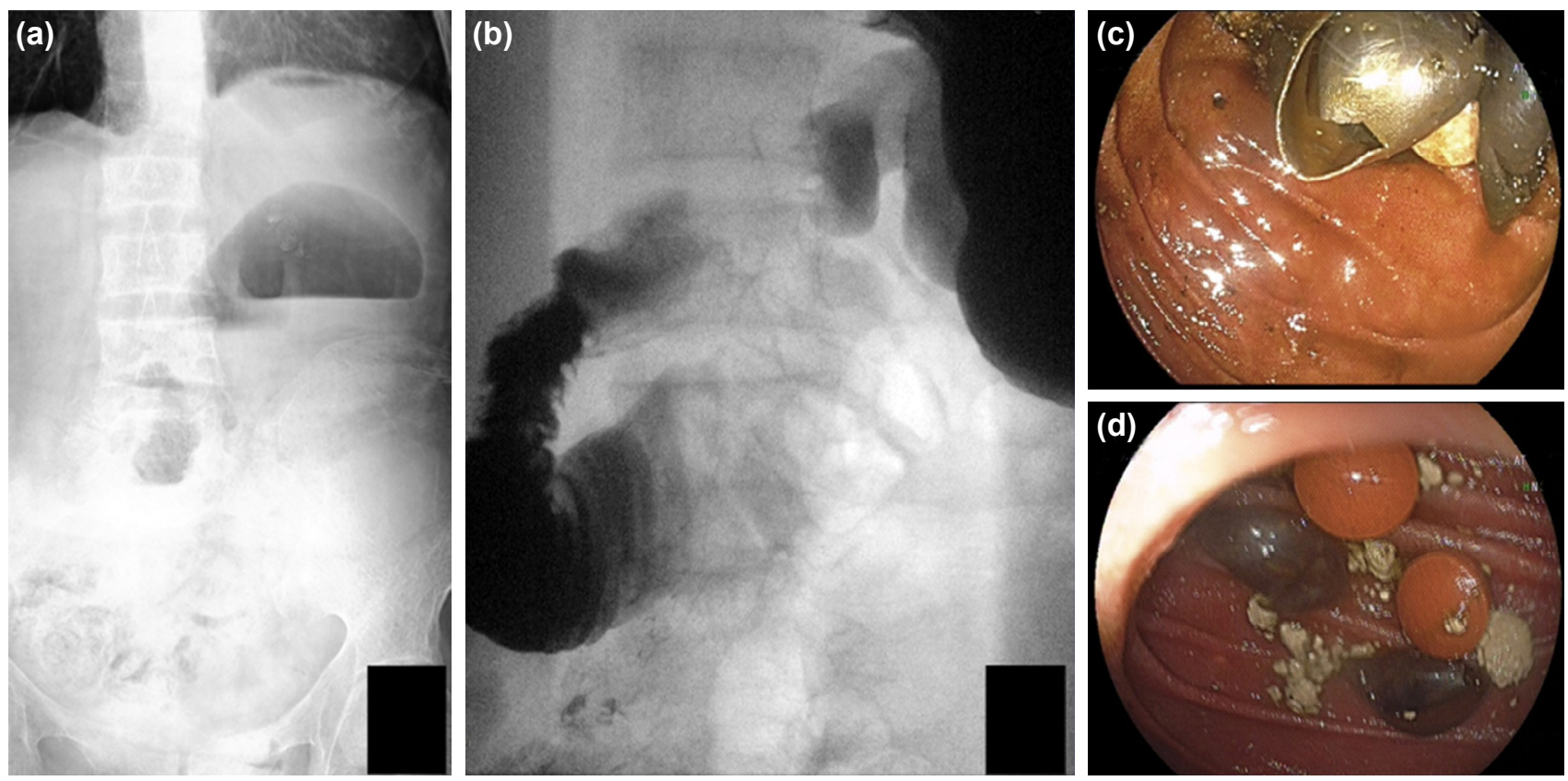

Figure 1. (a) AXR image on admission. (b) Collection of barium contrast in the duodenum in upper GI series. (c, d) Thickened third segment of the duodenum, total obstruction of the duodenum, accumulated tablets in the third segment of the duodenum.

denal mass with a dilated intestinal segment proximal to this mass (Fig. 2a-d). The exact size of the mass cannot be measured due to the lack of IV contrast. Spontaneous intramural hematoma of the $4^{\text {th }}$ portion of duodenum was suspected to be the cause and prolonged coagulopathy was thought to be the etiology of this situation.

After the initial diagnosis, decompression with a NG tube was obtained and a conservative treatment modality was followed through. In the following period, drainage from the NG tube decreased steadily. After removal of the NG tube, the patient was given standard oral feeding regimen which was tolerated without any problems.

In the end, no operative intervention was needed and obstructive symptoms resolved under conservative therapy without any complications. The patient was discharged with low molecular weight heparin treatment which was continued for six months. After an uneventful six months, the treatment ended and no additional intervention was needed in this time period.

\section{DISCUSSION}

Spontaneous intramural duodenal hematoma is commonly associated with coagulation abnormalities resulting secondary to usage of anticoagulant drugs. Oral anticoagulants such as warfarin are widely used and the most common complication is bleeding. ${ }^{[9]}$ According to recent studies spontaneos intramural hematomas most commonly involve jejenum followed by ileum and duodenum; which is different than the traumatic intramural hematomas which mostly involves duodenum. ${ }^{[10]}$

A spontaneous intramural duodenal hematoma usually presents with intense abdominal pain followed by nausea and vomiting. Patients can be symptomatic for several days prior to presentation or diagnosis. ${ }^{[1-14]}$ Several radiographic features have been described. These include a thickened intestinal wall on ultrasonography or circumferential wall thickening, intramural hyperdensity, luminal narrowing and intestinal obstruction on CT. ${ }^{[15,16]}$ The problem is; these kind of radiologic abnormalities are not specific for intestinal tract hematomas and can resemble other pathologies. ${ }^{[16]}$ So the clinician should have a low threshold in suspecting of a possible intramural hematoma diagnosis.

Apart from conventional USG and CT, UGI endoscopy is also a powerful tool in these cases. With the help of endoscopy, it is possible to both visualize and cure small-bowel hematomas. $\left[{ }^{[17,18]}\right.$ Young Lee et al. ${ }^{[19]}$ presented a case of an intramural
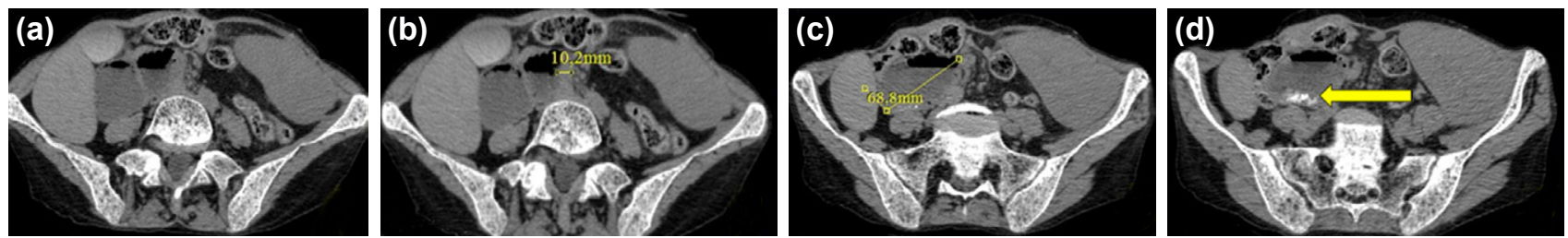

Figure 2. (a, b) Duodenal wall thickening. (c) A thickened third segment of the duodenum. (d) Radio-opaque image of accumulated tablets in the third segment of the duodenum. 
duodenal hematoma secondary to acute pancreatitis, which was cured by endoscopic decompression.

For management of spontaneous intestinal hematoma, there is not a global concensus on one specific approach. It usually responds well to conservative management within 10-15 days. $[12,13]$ The conservative management consists of stopping oral anticoagulants immediately and starting a simultaneous infusion of FFP/vitamin $\mathrm{K}$ for reversal of anticoagulant effects. If the patient presents with obstructive symptoms; a NG tube should be administered swiftly and the drainage should be monitored closely.

Most cases have good prognosis with conservative care and the hematoma can start to regress as early as the first week. But more often, a two-month period is needed for complete resolution. If a lesion persists for more than 2 months without any significant resolution, other causes such as inflammatory bowel disease, tuberculosis, lymphoma, etc. should be suspected and investigated thoroughly. ${ }^{[14]}$ Both short-term and long-term outcomes are good in the absence of any other concurrent conditions.

A spontaneous intramural intestinal hematoma especially a duodenal one is a rare complication stemming from anticoagulating treatment modalities. Even though it is sometimes hard to diagnose properly, once the diagnosis is made it has a mild prognosis and it is a manageable complication with conservative means.

\section{Conflict of interest: None declared.}

\section{REFERENCES}

1. McLauchlan, J. Fatal false aneurysmal tumour occupying nearly the whole of the duodenum. Lancet 2 1838;30:203-5. [CrossRef]

2. Hayashi K, Futagawa S, Kozaki S, Hirao K, Hombo Z. Ultrasound and CT diagnosis of intramural duodenal hematoma. Pediatr Radiol 1988;18:167-8. [CrossRef]

3. Jewett TC Jr, Caldarola V, Karp MP, Allen JE, Cooney DR. Intramural hematoma of the duodenum. Arch Surg 1988;123:54-8. [CrossRef]

4. Polat C, Dervisoglu A, Guven H, Kaya E, Malazgirt Z, Danaci M, et al. Anticoagulant-induced intramural intestinal hematoma. Am J Emerg Med 2003;21:208-11. [CrossRef]

5. Tseng CY, Fan JS, Yang SC, Huang HH, Chen JD, Yen DH, et al. Anti- coagulant-induced intramural intestinal hemorrhage. Am J Emerg Med 2010;28:937-40. [CrossRef]

6. Abbas MA, Collins JM, Olden KW. Spontaneous intramural smallbowel hematoma: imaging findings and outcome. AJR Am J Roentgenol 2002;179:1389-94. [CrossRef]

7. Grasshof C, Wolf A, Neuwirth F, Posovszky C. Intramural duodenal haematoma after endoscopic biopsy: case report and review of the literature. Case Rep Gastroenterol 2012;6:5-14. [CrossRef]

8. Bettler S, Montani S, Bachmann F. Incidence of intramural digestive system hematoma in anticoagulation. Epidemiologic study and clinical aspects of 59 cases observed in Switzerland (1970-1975). [Article in French]. Schweiz Med Wochenschr 1983;113:630-6.

9. Palareti G, Leali N, Coccheri S, Poggi M, Manotti C, D’Angelo A, et al. Bleeding complications of oral anticoagulant treatment: an inception-cohort, prospective collaborative study (ISCOAT). Italian Study on Complications of Oral Anticoagulant Therapy. Lancet 1996;348:423-8.

10. Chaiteerakij R, Treeprasertsuk S, Mahachai V, Kullavanijaya P. Anticoagulant-induced intramural intestinal hematoma: report of three cases and literature review. J Med Assoc Thai 2008;91:1285-90.

11. Gutstein DE, Rosenberg SJ. Nontraumatic intramural hematoma of the duodenum complicating warfarin therapy. Mt Sinai J Med 1997;64:339-41.

12. Sorbello MP, Utiyama EM, Parreira JG, Birolini D, Rasslan S. Spontaneous intramural small bowel hematoma induced by anticoagulant therapy: review and case report. Clinics (Sao Paulo) 2007;62:785-90.

13. Takishima T, Hirata M, Kataoka Y, Naito T, Ohwada T, Kakita A. Delayed development of obstructive jaundice and pancreatitis resulting from traumatic intramural hematoma of the duodenum: report of a case requiring deferred laparotomy. J Trauma 2000;49:160-2. [CrossRef]

14. Abbas MA, Collins JM, Olden KW, Kelly KA. Spontaneous intramural small-bowel hematoma: clinical presentation and long-term outcome. Arch Surg 2002;137:306-10. [CrossRef]

15. Lane MJ, Katz DS, Mindelzun RE, Jeffrey RB Jr. Spontaneous intramural small bowel haemorrhage: importance of non-contrast CT. Clin Radiol. 1997 May;52(5):378-80. [CrossRef]

16. Rauh P, Uhle C, Ensberg D, Rickes S, Mönkemüller K, Fry L, et al. Sonographic characteristics of intramural bowel hematoma.J Clin Ultrasound 2008;36:367-8. [CrossRef]

17. Shinozaki S, Yamamoto H, Kita H, Yano T, Miyata T, Sunada K, et al. Direct observation with double-balloon enteroscopy of an intestinal intramural hematoma resulting in anticoagulant ileus. Dig Dis Sci 2004;49:902-5. [CrossRef]

18. Kwon CI, Ko KH, Kim HY, Hong SP, Hwang SG, Park PW, et al. Bowel obstruction caused by an intramural duodenal hematoma: a case report of endoscopic incision and drainage. J Korean Med Sci 2009;24:179-83.

19. Lee JY, Chung JS, Kim TH. Successful endoscopic decompression for intramural duodenal hematoma with gastric outlet obstruction complicating acute pancreatitis. Clin Endosc 2012;45:202-4. [CrossRef]

\section{OLGU SUNUMU - ÖZET}

\section{Böbrek nakli sonrası erken dönemde antikoagülan kullanımına bağlı gelişen duodenum intramural hamatomu: Olgu sunumu \\ Dr. Adem Bayraktar, Dr. Leman Damla Ercan, Dr. Hüseyin Bakkaloğlu, Dr. Ali Fuat Kaan Gök, Dr. Mehmet İlhan, Dr. Ali Emin Aydın}

İstanbul Üniversitesi İstanbul Tıp Fakültesi, Genel Cerrahi Anabilim Dalı, İstanbul

Spontan duodenal hematom, antikolagülan tedavi uygulanan hastalarda nadir rastlanan bir komplikasyondur. Bu olgu örneğinde, kadavradan böbrek nakli sonrası gelişen paroksismal atriyal fibrillasyon nedeniyle oral antikoagülan tedavi almakta olan hastada karşılaşılan spontan duodenal hematom olgusu sunulmaktadır. Karın ağrısı, bulantı-kusma şikayetleriyle başvuran ve tam duodenal obstrüksiyon saptanan hastada spontan duodenal hematom tanısı konulduktan sonra konservatif tedavi ile iyi bir prognoz sağlanmıştır.

Anahtar sözcükler: Antikoagülan; böbrek nakli; intramural duodenal hematom.

Ulus Travma Acil Cerrahi Derg 2018;24(6):594-596 doi: 10.5505/tjtes.2018.43637 